\title{
7,8-dimethoxycoumarin Attenuates the Expression of IL-6, IL-8, and CCL2/MCP-1 in TNF- $\alpha$-Treated HaCaT Cells by Potentially Targeting the NF- $\kappa B$ and MAPK Pathways
}

\author{
Nari Lee ${ }^{1}$, You Chul Chung ${ }^{1}$, Choon Il Kang ${ }^{2}$, Sung-Min Park ${ }^{3}$ and Chang-Gu Hyun ${ }^{1, *}$ \\ 1 Department of Chemistry and Cosmetics, Jeju National University, Jeju 63243, Korea \\ 2 Jeju Indi Inc., Seogwipo-si, Jeju 63635, Korea \\ 3 R\&D Center, CoSeed Bio Pham Co., Chungbuk 28161, Korea \\ * Correspondence: cghyun@jejunu.ac.kr; Tel.: +82-64-754-3542
}

Received: 13 April 2019; Accepted: 5 July 2019; Published: 8 July 2019

\begin{abstract}
DMC, C11H10O4), a natural coumarin compound, is present in Citrus plants including Citrus decumana and grapefruit. It is known to have protective effects on the kidneys against Cisplatin and ischemia-reperfusion injury. However, the underlying mechanisms of its inhibitory effects on skin inflammation have not been investigated in vitro. Tumor necrosis factor (TNF)- $\alpha$ is known to be one of the main causative agents of skin inflammation. It induces pro-inflammatory cytokines and chemokines by activating nuclear factor- $\mathrm{kB}$ (NF- $\mathrm{kB}$ ) and mitogen-activated protein kinase (MAPK) signaling. In this study, we investigated the inhibitory effect of DMC on the expression of pro-inflammatory cytokines and chemokines in TNF- $\alpha$-treated human keratinocyte HaCaT cells. Pretreatment with DMC inhibited TNF- $\alpha$-treated cytokines (interleukin 6; IL-6) and chemokines (IL-8 and monocyte chemoattractant protein-1). In addition, DMC significantly inhibited TNF- $\alpha$-treated NF- $\mathrm{KB}$ activation and phosphorylation of MAPKs, such as c-Jun N-terminal kinases (JNK) and extracellular-signal-regulated kinase (ERK). These results suggest that DMC may elicit an anti-inflammatory response by suppressing TNF- $\alpha$-treated activation of NF-KB and MAPK pathways in keratinocytes. Hence, it might be a useful therapeutic drug against skin inflammatory diseases.
\end{abstract}

Keywords: 7,8-dimethoxycoumarin; human keratinocyte HaCaT cell; skin inflammation; NF- $\mathrm{BB}$; MAPK

\section{Introduction}

The skin comprises three main layers, namely, epidermis, dermis, and subcutaneous fat layer. It is by far the largest organ in the body, protecting it from chemicals, disease, and ultraviolet and physical damage [1,2]. The epidermis, located surface-most on the skin, comprises five major layers: the stratum corneum, stratum lucidum, stratum granulosum, stratum spinosum, and stratum basale. It consists of a specific constellation of cell types, such as keratinocytes, langerhans cells, merkel cells, and melanocytes, of which keratinocytes are the predominant type, constituting approximately $95 \%$ of the cells. The keratinocytes can be found in the basal layer of the skin and are called basal cells or basal keratinocytes [3,4].

The primary function of epidermal keratinocytes is to provide a barrier against pathogens. Once the skin pathogens penetrate the epidermis, keratinocytes begin to produce various cytokines and chemokines such as TNF- $\alpha$, IL-6, IL-8, and monocyte chemoattractant protein-1 (MCP-1), which lead to the pathogenesis of skin inflammation. These factors also increase infiltration of 
immunocytes into the area of inflammation in the skin. Therefore, down-regulation of pro-inflammatory cytokine and chemokine production in keratinocytes can be an effective strategy in the treatment of inflammatory skin diseases [5-9]. According to various studies, transcription factors, such as nuclear factor kappa-light-chain-enhancer of activated B cells (NF- $k$ B) and mitogen-activated protein kinase (MAPK), play critical roles in the cytokine and chemokine production mediated by TNF- $\alpha$ and/or interferon-gamma (IFN- $\gamma$ ) in human epidermal keratinocytes. Hence, these transcription factors act as both primary inducers and targets of the immune responses occurring in the keratinocytes. As NF- $\kappa \mathrm{B}$ and MAPK are critical in skin immunopathology, the development of an effective strategy to block these pathways is a key step to controlling skin inflammation [10-12].

Currently, both steroids and non-steroidal anti-inflammatory drugs are prescribed clinically to reduce skin inflammatory conditions such as atopic dermatitis and psoriasis. They decrease chemokine and cytokine production by inhibiting the activity of NF-kB or MAPK pathways [13-16]. However, steroids are immunosuppressive agents that inhibit immunocyte functions, and long-term dosage of non-steroidal anti-inflammatory drugs can cause side effects, such as allergic reactions or drug resistance [4,12]. Therefore, the development of novel, complementary, and alternative drugs that can alleviate inflammatory skin diseases is of particular interest. Recent studies have found that flavonoids or coumarins isolated from plants may have potential therapeutic effects against skin inflammation [17-19].

7,8-dimethoxycoumarin (DMC, Figure 1a), a natural coumarin compound, is present in several medicinal plants, including Daphne koreana, Astianthus viminalis, Zanthoxylum leprieurii, and Citrus decumana. It is known to possess antioxidant and anti-inflammatory biological activities. DMC has been shown to protect the kidney against $\mathrm{CP}$ and I/R injury by virtue of these properties and inactivation of the mitochondrial permeability transition pore opening. DMC isolated from ethyl acetate extract of $C$. decumana has been shown to have an ameliorative effect on gastric inflammation [20-24].

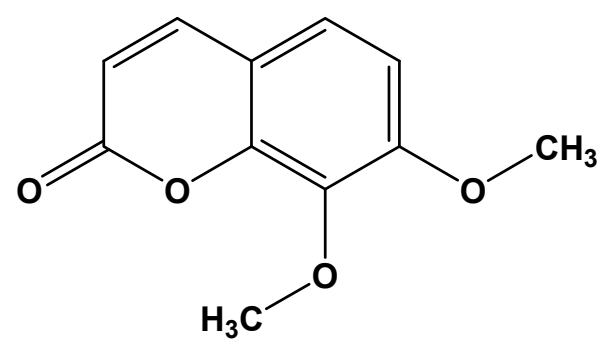

(a)

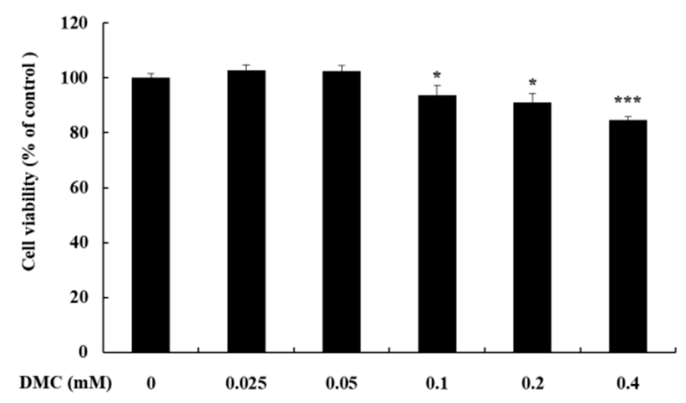

(b)

Figure 1. Effect of 7,8-dimethoxycoumarin (DMC) on the viability of HaCaT cells. (a) Structures of 7,8-dimethoxycoumarin. (b) Cells were treated with DMC $(0.025,0.05,0.1,0.2$, and $0.4 \mathrm{mM})$ for $20 \mathrm{~h}$. Data are presented as mean \pm standard deviation (SD) of at least four independent experiments $(n=4)$. ${ }^{*} p<0.05,{ }^{* * *} p<0.001$ vs. control.

However, the anti-inflammatory effects and the basic mechanism of action of DMC in human keratinocytes have not yet been studied. Therefore, in this study, we examine the inhibitory effect of DMC on pro-inflammatory cytokine or chemokine production and the underlying molecular mechanism in TNF- $\alpha$-treated human keratinocyte HaCaT cells. Our results suggest that DMC may exert anti-inflammatory effects by inhibiting the activation of NF- $\mathrm{KB}$ and MAPKs in keratinocytes, and hence the possibility of its application as a therapeutic agent for skin inflammation can be explored. 


\section{Materials and Methods}

\subsection{Chemicals and Reagents}

7,8-dimethoxycoumarin (DMC, C11H10O4), tumor necrosis factor- $\alpha$ (TNF- $\alpha$ ), 3-(4,5-dimethylthiazol2-yl)-2,5-diphenyltetrazolium bromide (MTT), ammonium pyrrolidinedithiocarbamate (APDTC), and protease inhibitor cocktail were purchased from Merck (Darmstadt, Hesse, Germany). Dulbecco's Modified Eagle medium, fetal bovine serum (FBS), penicillin-streptomycin (5000 U/mL), trypsin-ethylenediaminetetraacetic acid, BCA protein assay kit, and PD98059 (ERK inhibitor) were purchased from Thermo Fisher Scientific (Waltham, MA, USA). IL-6 IL-8, CCL2/MCP-1, and enzyme-linked immunosorbent assay (ELISA) kit were purchased from R\&D Systems, Inc. (Minneapolis, MN, USA). Antibodies against P-p38(Thr180/Tyr182), T-p38, P-JNK(Thr183/Tyr185), T-JNK, P-ERK(Thr202/Tyr204), T-ERK, P-p105(Ser933), T-p105, P-p65(Ser536), T-p65, and $\beta$-actin were purchased from Cell Signaling Technology (Danvers, MA, USA). SP600125 (JNK inhibitor) and SB203580 (p38 inhibitor) were purchased from Cayman Chemical (Ann Arbor, MI, USA) and Calbiochem (San Diego, CA, USA), respectively. Dimethyl sulfoxide (DMSO), radioimmunoprecipitation (RIPA) buffer, enhanced chemiluminescence reagent (ECL kit), and 2×Laemmli sample buffer were obtained from Biosesang (Sungnam-si, Gyeonggi-do, Republic of Korea) and Bio-Rad (Hercules, CA, USA), respectively.

\subsection{Cell Culture}

The human keratinocyte cell line, HaCaT, was purchased from CLS Cell Lines Service GmbH (Eppelheim, Heidelberg, Baden-Württemberg, Germany). The cells were subcultured in Dulbecco's modified Eagle's medium containing 10\% FBS and 1\% penicillin-streptomycin at 2-day intervals and maintained in an incubator at $37^{\circ} \mathrm{C}$ and $5 \% \mathrm{CO}_{2}$.

\subsection{Cell Viability Assay}

Cell viability upon DMC treatment was measured by MTT assay. HaCaT cells were seeded in a 24 -well plate at $1.5 \times 10^{5}$ cells $/ \mathrm{mL}$ and pre incubated for $24 \mathrm{~h}$. The supernatant was removed, $\operatorname{DMC}(0.025,0.05,0.1,0.2$, and $0.4 \mathrm{mM})$ was added to the medium without FBS, and each concentration was cultured again for $24 \mathrm{~h}$. Then, $400 \mu \mathrm{L}$ of $0.4 \mathrm{mg} / \mathrm{mL}$ MTT solution was added to each well and incubated for $4 \mathrm{~h}$. After completion of the reaction, the cell culture supernatant was removed; the formazan crystals formed were completely dissolved using DMSO, and the absorbance was measured at $570 \mathrm{~nm}$ using a microplate reader (SUNRISE, TECAN Austria GmbH).

\subsection{Measurement of Cytokine Concentration}

To investigate the effect of DMC on the production of cytokines such as IL-6, IL-8, and CCL2/MCP-1, $\mathrm{HaCaT}$ cells were seeded in a 24 -well plate at $1.5 \times 10^{5}$ cells $/ \mathrm{mL}$ and cultured for $24 \mathrm{~h}$. Next, the supernatant was removed, DMC $(0.025,0.05,0.1$, and $0.2 \mathrm{mM})$ and TNF- $\alpha(50 \mathrm{ng} / \mathrm{mL})$ were added along with FBS-free medium, and the cells were cultured for $24 \mathrm{~h}$. Cell culture supernatants were collected, and the level of each of the cytokines was measured using an ELISA kit.

\subsection{Western Blot Assay}

$\mathrm{HaCaT}$ cells were seeded in a $60-\mathrm{mm}$ culture dish at $3 \times 10^{5}$ cells/well and cultured for $24 \mathrm{~h}$. The supernatant was removed, and various concentrations of DMC $(0.05,0.1$, and $0.2 \mathrm{mM})$ and TNF- $\alpha(50 \mathrm{ng} / \mathrm{mL})$ were added in the absence of FBS. The cultured cells were washed twice with $1 \times$ phosphate-buffered saline, lysed with lysis buffer (150 mM sodium chloride, 1\% Triton X-100, $1 \%$ sodium deoxycholate, $0.1 \%$ SDS, $50 \mathrm{mM}$ Tris- $\mathrm{HCl} \mathrm{pH} 7.5$, and $2 \mathrm{mM}$ EDTA, sterile solution) and protease inhibitor cocktail (1.0\%) at $4{ }^{\circ} \mathrm{C}$ for $20 \mathrm{~min}$ and centrifuged at 15,000 rpm for 20 min. Protein concentration was determined by quantitative analysis with the BCA protein assay kit, using bovine 
serum albumin (BSA) as a standard. Proteins were quantitated, and $20 \mu \mathrm{g}$ of each protein was loaded in an SDS-PAGE gel and then transferred to a polyvinylidene difluoride (PVDF) membrane. The membrane was blocked with 5\% non-fat skim milk (blocking buffer) dissolved in tris-buffered saline containing $0.1 \%$ Tween 20 (TBS-T) for $2 \mathrm{~h}$ at room temperature and then washed thrice with TBS-T. Then, the primary antibody, dissolved at a ratio of 1:1000, was added to the blots and incubated for $24 \mathrm{~h}$. After completion of the reaction, the blots were washed five times at $10 \mathrm{~min}$ intervals with TBS-T and then incubated with secondary antibody at a ratio of 1:3000 for $2 \mathrm{~h}$. The blots were washed again with TBS-T five times at 10 min intervals. Proteins were detected using the ECL kit, and images were captured and analyzed using Chemidoc (Fusion solo 6S.WL, VILBER LOURMAT, France).

\subsection{Statistical Analysis}

The results of all experiments are expressed as mean \pm standard deviation (mean $\pm \mathrm{SD}$ ). Statistical significance and $p$-values were calculated using the Student's $t$-test.

\section{Results}

\subsection{Effect of DMC on Viability of HaCaT Cells}

To confirm that the anti-inflammatory effect of DMC is not due to cell apoptosis, we first assessed the cytotoxicity of DMC on HaCaT cells using MTT assay. HaCaT cells were treated with various concentrations of DMC $(0.025,0.05,0.1,0.2$, and $0.4 \mathrm{mM})$ for $20 \mathrm{~h}$. The viability of the DMC-treated cells, compared to that of the untreated cells (control), was significantly different at $0.1,0.2$, and $0.4 \mathrm{mM}$ concentrations. DMC did not show any toxic effects on cell viability up to $0.2 \mathrm{mM}$ concentration (Figure $1 \mathrm{~b}$ ). In contrast, cell survival rate was $85 \%$ at a DMC concentration of $0.4 \mathrm{mM}$. Therefore, subsequent experiments were conducted at the highest concentration of DMC at $0.2 \mathrm{mM}$, which was not cytotoxic.

\subsection{Effects of DMC on the Expression of Pro-Inflammatory Cytokines in TNF- $\alpha$-treated HaCaT Cells}

When keratinocytes are induced with TNF- $\alpha$, which is known as a typical pro-inflammatory cytokine that causes inflammation, abnormal expression of cytokines and chemokines occurs. We, therefore, examined the inhibition effects of DMC on cytokine and chemokine production in TNF- $\alpha$-treated HaCaT cells. The cells were pretreated with DMC $(0.025,0.05,0.1$, and $0.2 \mathrm{mM})$ for $1 \mathrm{~h}$ and then stimulated with TNF- $\alpha(50 \mathrm{ng} / \mathrm{mL})$ for $20 \mathrm{~h}$; subsequently, to determine the IL-6, IL-8, and CCL2/MCP-1 levels in cell supernatants, we used the ELISA kit. MTT assay was used to confirm the cell survival rate of DMC and TNF- $\alpha$-treated controls (Figure $2 \mathrm{a}$ ). TNF- $\alpha$ treatment significantly increased the production of IL-6, IL-8, and CCL2/MCP-1 in the cell supernatant, whereas pretreatment with DMC $(0.025,0.05,0.1$, and $0.2 \mathrm{mM})$ inhibited the production of cytokine or chemokine in a concentration-dependent manner (Figure $2 b-d$ ).

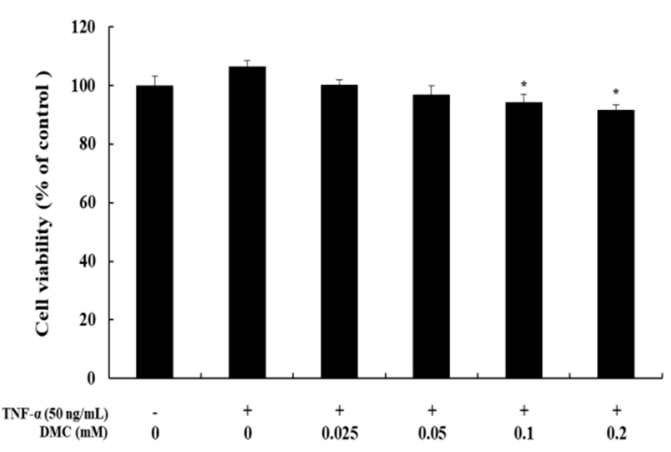

(a)

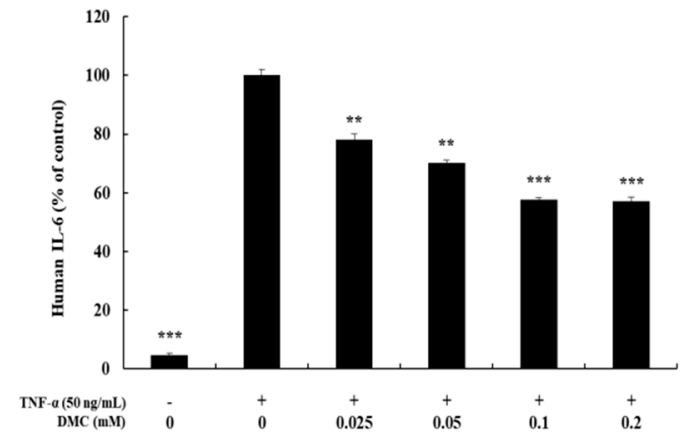

(b)

Figure 2. Cont. 


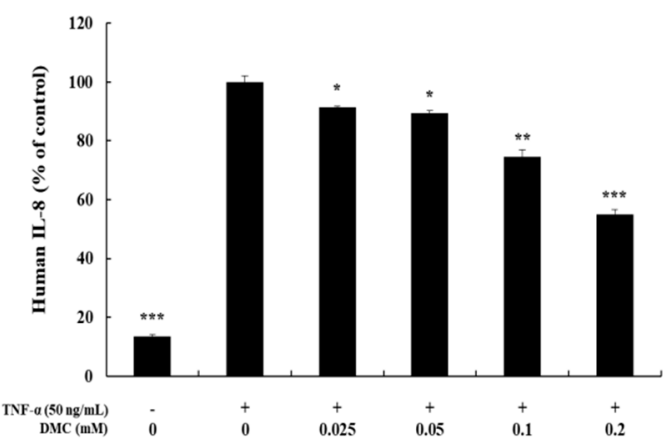

(c)

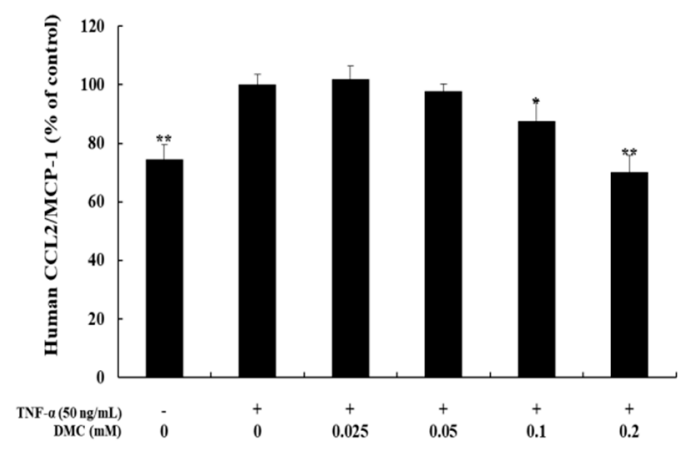

(d)

Figure 2. Effects of DMC on the pro-inflammatory cytokine production and viability of tumor necrosis factor (TNF)- $\alpha$-treated HaCaT cells. The cells were treated with DMC $(0.025,0.05,0.1$, and $0.2 \mathrm{mM})$ and TNF- $\alpha$ (50 ng/mL) for $20 \mathrm{~h}$. TNF- $\alpha$-treated cells were used as a positive control. (a) Cell viability was determined by 3-(4,5-dimethylthiazol-2-yl)-2,5-diphenyltetrazolium bromide (MTT) assay. (b); (c); and (d) production of IL-6, IL-8, and CCL2/MCP-1, were measured using the culture supernatant of $\mathrm{HaCaT}$ cells treated as mentioned above by ELISA. The results are expressed as percentage values compared to that of the control cells. Data are presented as mean $\pm \operatorname{SD}(\mathrm{n}=4) .{ }^{*} p<0.05,{ }^{* *} p<0.01$, and ${ }^{* * *} p<0.001$ vs. non treated control or TNF- $\alpha$ - treated control.

\subsection{Effect of TNF- $\alpha$ on the MAPKs and NF- $\kappa B$ Pathway in HaCaT Cells}

In previous studies, it has been reported that $\mathrm{HaCaT}$ cells differ in the degree of phosphorylation of MAPKs and NF- $\mathrm{KB}$ signaling pathways upon TNF- $\alpha$ stimulation for different time periods $[5,25,26]$. Hence, before confirming the signaling pathway involved in mediating the anti-inflammatory effects of DMC, we examined the time at which maximum expression of phosphorylated MAPKs and NF- $\mathrm{KB}$ signaling intermediates is seen, by treating HaCaT cells with TNF- $\alpha(50 \mathrm{ng} / \mathrm{mL})$ for $5,10,15,30$, and $60 \mathrm{~min}$. The expression of P-p38, P-JNK, and P-ERK in the MAPK signaling pathway was the highest at $10 \mathrm{~min}$ after TNF- $\alpha$ treatment (Figure 3a-d). In addition, the expression of P-p105 and P-p65 in the NF- $\kappa B$ signaling pathway was also the highest at $10 \mathrm{~min}$, and I $\kappa \mathrm{B}-\alpha$ was found to be degraded at $10 \mathrm{~min}$ (Figure $4 \mathrm{a}-\mathrm{d}$ ). Therefore, we treated cells with TNF- $\alpha$ for an optimum time of $10 \mathrm{~min}$ to determine the anti-inflammatory effects of DMC on MAPK and NF- $\mathrm{BB}$ signaling pathways.

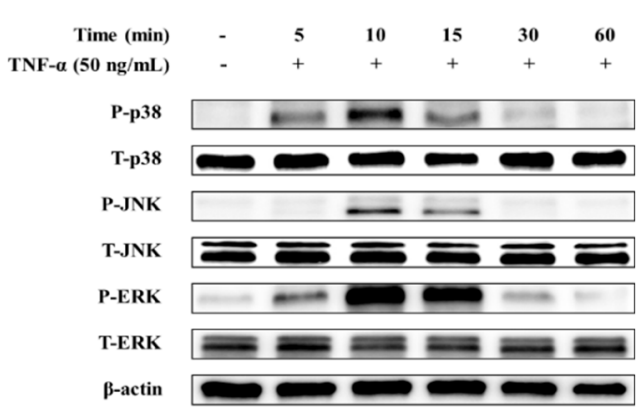

(a)

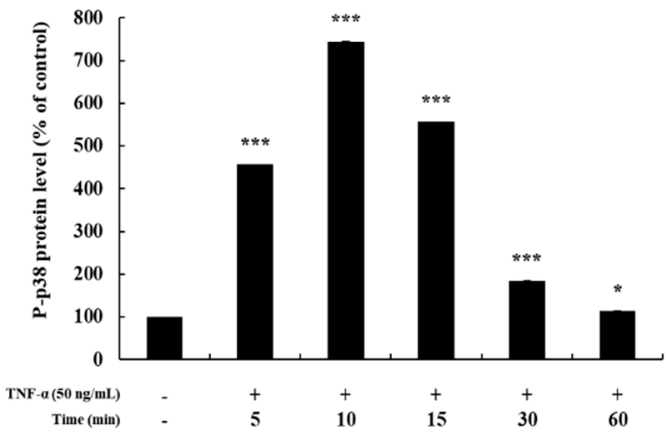

(b)

Figure 3. Cont. 


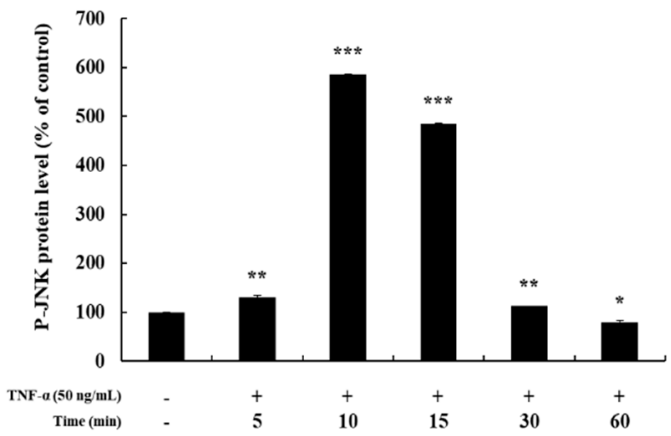

(c)

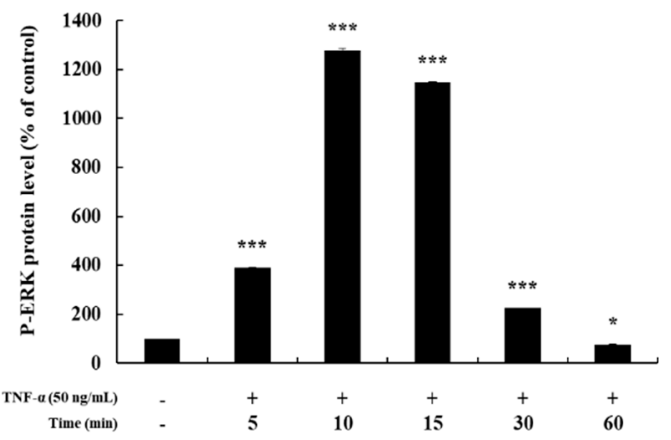

(d)

Figure 3. Effect of TNF- $\alpha$ on mitogen-activated protein kinase MAPK pathway in HaCaT cells. Cells were treated with TNF- $\alpha(50 \mathrm{ng} / \mathrm{mL})$ for 5, 10, 15, 30, and $60 \mathrm{~min}$, and cell lysates were prepared for western blot analysis. Data are presented as the mean $\pm \operatorname{SD}(\mathrm{n}=3) .{ }^{*} p<0.05,{ }^{* *} p<0.01$, and ${ }^{* * *} p<0.001$ vs. control.

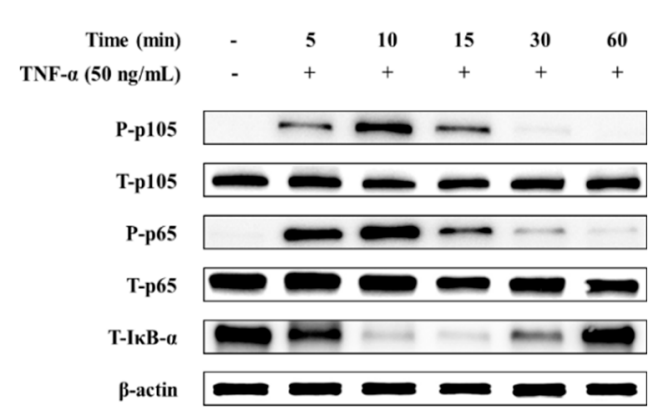

(a)

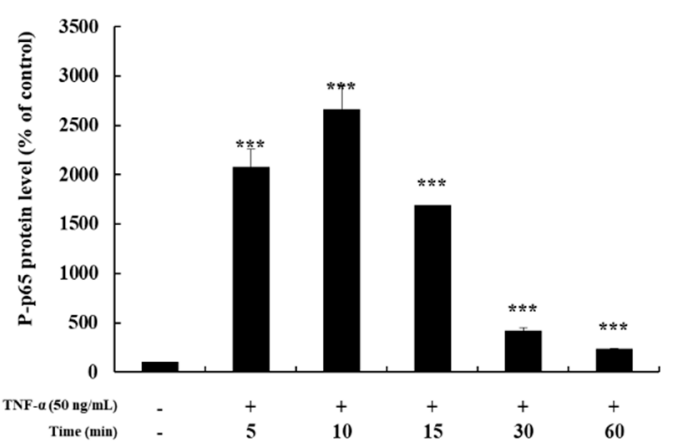

(c)

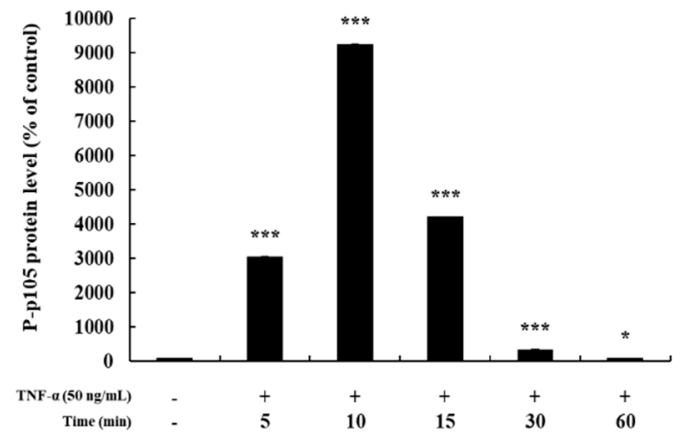

(b)

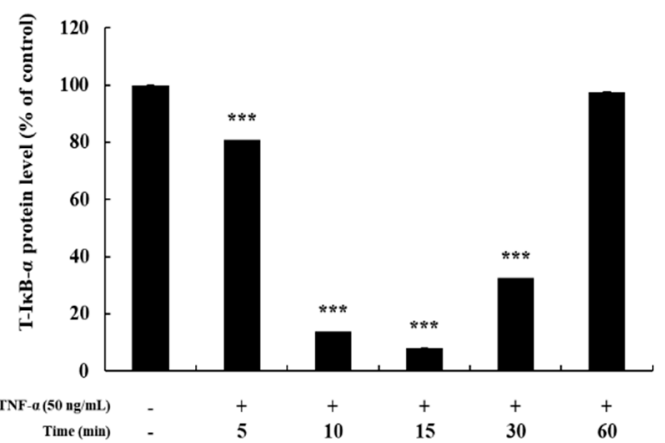

(d)

Figure 4. Effect of TNF- $\alpha$ on NF- $\mathrm{kB}$ pathway in HaCaT cells. Cells were treated with TNF- $\alpha(50 \mathrm{ng} / \mathrm{mL})$ for $5,10,15,30$, and $60 \mathrm{~min}$, and cell lysates were prepared for western blot analysis. Data are presented as the mean $\pm \mathrm{SD}(\mathrm{n}=3) .{ }^{*} p<0.05,{ }^{* * *} p<0.001$ vs. control.

\subsection{Effect of DMC on the MAPK Pathway in TNF- $\alpha$-Treated HaCaT Cells}

Previously, TNF- $\alpha$ has been shown to activate the MAPK pathway in subsequent expression of pro-inflammatory mediators in keratinocytes [6]. To explore the correlation between MAPK pathway activation and pro-inflammatory mediators, we further investigated the regulatory effect of DMC on ERK, p38, and JNK phosphorylation by western blot analysis using phospho-specific antibodies. HaCaT cells were pretreated with SB203580 (p38 inhibitor, $10 \mu \mathrm{M}$ ), SP600125 (JNK inhibitor, $20 \mu \mathrm{M}$ ), and PD98059 (MEK1/2 inhibitor, $20 \mu \mathrm{M}$ ) for $1 \mathrm{~h}$ before TNF- $\alpha$ treatment. Compared to that in the control group, SB203580, SP600125, and PD98059 suppressed the TNF- $\alpha$-treated phosphorylation of 
MAPKs. We determined the alterations in the phosphorylation levels of MAPKs by calculating the P-ERK/T-ERK, P-p38/T-p38, and P-JNK/T-JNK ratios in TNF- $\alpha$-treated HaCaT cells. DMC treatment reduced TNF- $\alpha$-induced phosphorylation of ERK and JNK in a concentration-dependent manner without affecting the total protein levels, whereas it had a no effect on P-p38 levels. In particular, JNK and ERK phosphorylation were inhibited by $49 \%$ and $38 \%$, respectively, at $0.1 \mathrm{mM}$ DMC concentration compared to that in the TNF- $\alpha$-treated control group (Figure 5). These results suggest that activation of p38, JNK, and ERK is partially involved in TNF- $\alpha$-mediated stimulation of pro-inflammatory mediators, and that DMC can modulate MAPKs signaling cascades.

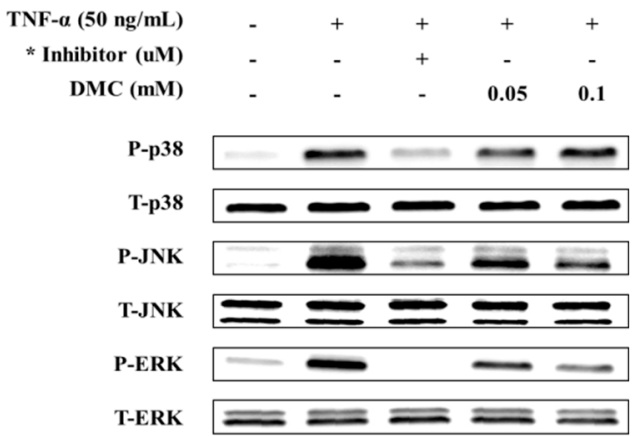

(a)

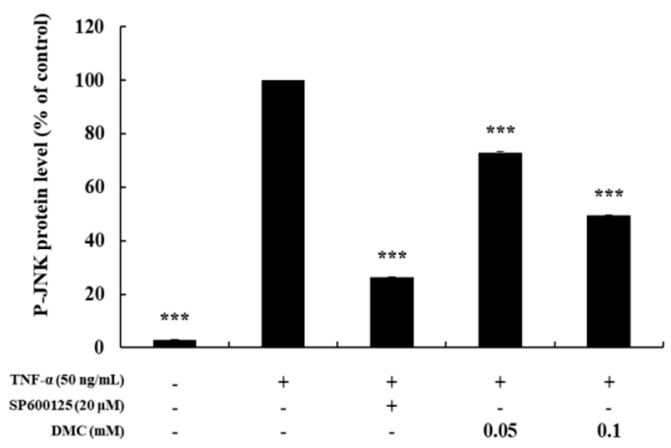

(c)

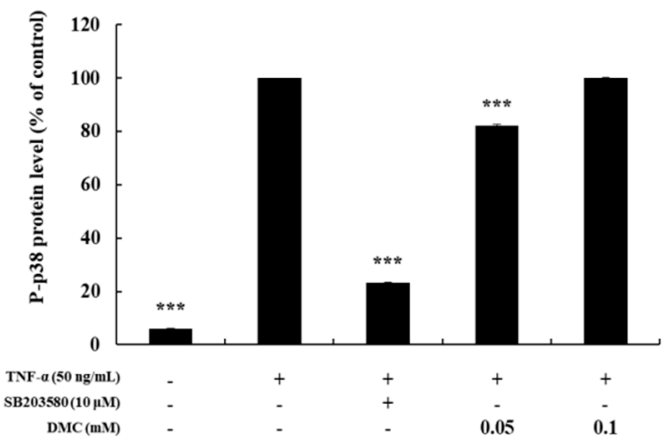

(b)

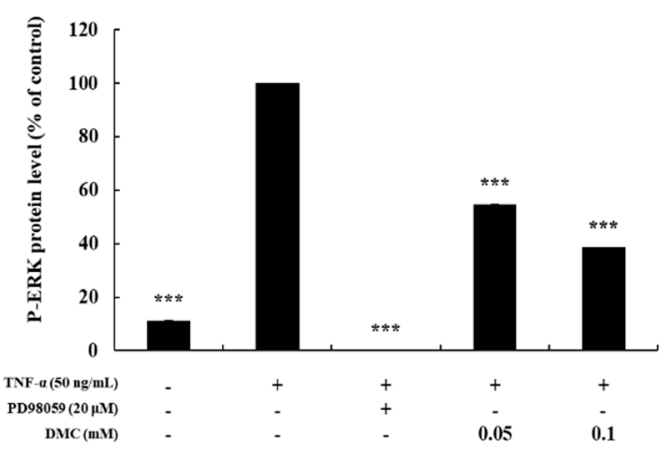

(d)

Figure 5. Effect of DMC on the expression of p38, c-Jun N-terminal kinases (JNK), and extracellularsignal-regulated kinase (ERK) in TNF- $\alpha$-treated HaCaT cells. (a) cells were pretreated with various concentrations of DMC (0.05 and $0.1 \mathrm{mM})$ for $1 \mathrm{~h}$ and then stimulated with TNF- $\alpha$ for $10 \mathrm{~min}$ followed by western blotting of the cell lysates with the indicated antibodies. (b); (c); and (d) quantitation of the protein levels of P-p38 (b), P-JNK (c), and P-ERK (d), are presented as mean \pm SD $(\mathrm{n}=3) .{ }^{* * *} p<0.001$ vs. TNF- $\alpha$ - treated control.

\subsection{Effect of DMC on the NF- $\kappa B$ Pathway in TNF- $\alpha$ Treated HaCaT Cells}

Regulation of NF- $\mathrm{kB}$ signaling, like that of the MAPK pathway, is also an important therapeutic target for inflammation occurrence because activation of the NF- $\mathrm{KB}$ pathway relates to inflammatory disease. Previous studies have shown that IкB- $\alpha$ is degraded in the cytoplasm upon activation of the NF- $k B$ signaling pathway, and that p 65 and p105, which are associated with I $\kappa B-\alpha$, are activated in the cytoplasm by phosphorylation to promote inflammation [8]. Therefore, we examined whether DMC affected NF- $\mathrm{kB}$ pathway activation in TNF- $\alpha$-treated HaCaT cells. As expected, P-p105 and P-p65 were expressed at high levels at $10 \mathrm{~min}$ in HaCaT cells stimulated with TNF- $\alpha$. The treatment with the NF- $k B$ inhibitor, APDTC $(20 \mu \mathrm{M})$, also significantly decreased the levels of TNF- $\alpha$-treated P-p105 and P-p65. Compared to the TNF- $\alpha$-treated control group, treatment with DMC did not significantly affect TNF- $\alpha$-treated P-p105 activation at concentrations of $0.05,0.1$, and $0.2 \mathrm{mM}$ (Figure 6a). In contrast, it significantly inhibited the phosphorylation of NF- $\mathrm{kB} / \mathrm{p} 65$ in a dose-dependent manner, compared to 
that in the control group, indicating that DMC exerts its anti-inflammatory activity by inhibiting the signaling cascades leading to NF- $\mathrm{KB}$ activation (Figure $6 \mathrm{~b}$ ).

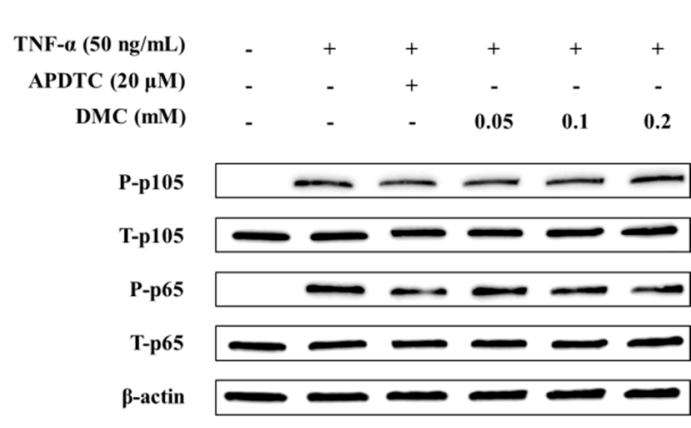

(a)

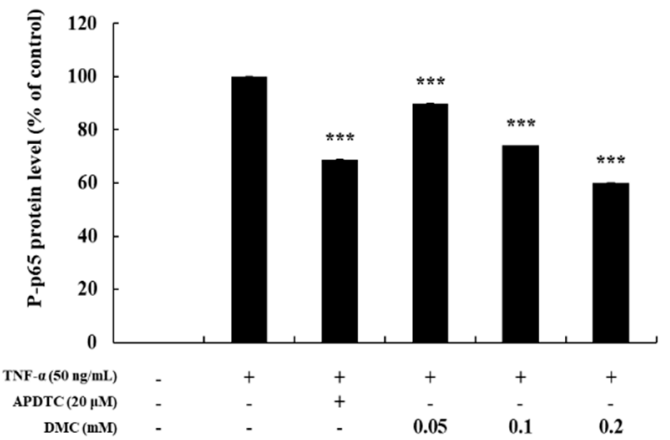

(b)

Figure 6. Effect of DMC on p105and p65 expression in TNF- $\alpha$-treated HaCaT cells. (a) Cells were pretreated with various concentrations of $\operatorname{DMC}(0.05,0.1$, and $0.2 \mathrm{mM})$ for $1 \mathrm{~h}$ and then stimulated with TNF- $\alpha$ for $10 \mathrm{~min}$ followed by western blotting of the cell lysates with the indicated antibodies. (b) Quantitation of protein level of P-p65 presented as mean \pm SD ( $n=3) .{ }^{* * *} p<0.001$ vs. TNF- $\alpha$ treated control.

\section{Discussion}

Coumarin(1, 2-benzopyrone), comprising benzene and heterocyclic rings of 2-pyrone has been described as having anticoagulant, anticancer, antioxidant, antiviral, antidiabetic, anti-inflammatory, anti-bacterial, anti-fungal, and anti-neurodegenerative properties. The benzopyrones can be separated into benzo-alpha-pyrones, where coumarin belongs, and benzo-gamma-pyrones, of which flavonoids are the main component [27-29]. At present, they are also used in functional foods and cosmetic ingredients, as they possess anti-melanogenic and grey-hair preventing activities [30,31]. In addition, various coumarin compounds have been reported to exhibit anti-inflammatory effects [32-34].

The structural features, biosynthetic pathway, and biological activity of hundreds of natural coumarin compounds from plants have been studied. Thus, they also occupy an important place in the field of natural product and organic chemistry.

Many studies have shown that flavonoids with methoxy structures are more noticeable in functional and industrial aspects than flavonoids with hydroxy structures [35-37]. Therefore, we conducted research to determine the effect of DMC on skin inflammation. Previous studies have indicated that DMC exerts antioxidant and anti-inflammatory effects, thereby protecting the kidney against CP and I/R injury [20-24]. However, studies on the inhibitory activity of DMC against pro-inflammatory cytokines and chemokines have been limited. Therefore, we investigated the anti-inflammatory activity of DMC and the signaling pathways involved using the human keratinocyte HaCaT cell line.

Keratinocytes are resident cells that are mainly involved in the pathogenesis of allergic skin diseases and in the initiation and progression of allergic contact dermatitis. During sensitization, allergen induces activation of keratinocytes, causing the release of inflammatory mediators such as cytokines or chemokines. TNF- $\alpha$, in turn, stimulates keratinocytes to produce and release various inflammatory proteins, including IL-8, IL-6, and MCP-1/CCL2 in an autocrine manner [5]. The unique, spontaneously immortalized, human keratinocyte HaCaT cells show properties similar to those of keratinocytes and are used in skin inflammatory symptoms and inflammatory in vitro tests for inflammatory stimuli such as TNF- $\alpha$. Therefore, HaCaT cells can be an ideal system to confirm the biological activities of DMC in vitro [10,38].

IL-8 is a cytokine that belongs to the CXC chemokine family strongly stimulated by IL- 1 and TNF- $\alpha$. IL-8 has been found to be expressed in keratinocytes and is released in response to inflammatory stimulation. IL-6 is also a representative cytokine and is known to induce the proliferation and migration of keratinocytes to cause inflammatory skin diseases such as psoriasis and atopic dermatitis. 
MCP-1 is a type of monocyte chemotactic activating factor, and it is a representative chemokine with regulated-upon-activation, normal T cell-expressed, and secreted (RANTES). MCP-1 is also known to be an important mediator of a variety of pathological conditions, including psoriasis and atopic dermatitis, and can be produced by fibroblasts, endothelial cells, mast cells, and keratinocytes $[8,12,14]$. Therefore, we studied the inflammation panel comprising the cytokine array, which indicated that DMC significantly inhibited the expression of chemokines and pro-inflammatory cytokines such as IL-8, IL-6, and MCP-1 in TNF- $\alpha$-stimulated HaCaT cells in a dose-dependent manner (Figure 2). These findings suggest that DMC may be useful to treat inflammatory skin diseases such as psoriasis and other related allergic diseases, based on its regulatory effects on chemokines and pro-inflammatory cytokines.

In keratinocytes, TNF- $\alpha$-stimulation activates MAPKs and NF- $\mathrm{B}$ pathways, which play an important role in immune responses [5,8]. We investigated the inhibitory effect of DMC on the activation of the MAPK pathway in TNF- $\alpha$-treated keratinocytes. Our results showed that the phosphorylation of ERK and JNK is decreased as the concentration of DMC increases (Figure 5).

The production of pro-inflammatory cytokines and chemokines in keratinocytes could also be regulated by transcription factors in the NF- $\kappa$ B pathway. Previous studies have reported that NF- $\kappa B$ signaling pathways are activated by various stimulators such as TNF- $\alpha$. In addition, the activation of the NF-KB signaling pathway has been reported in psoriasis and atopic dermatitis [11,12]. Thus, the transcription factors of these NF- $\kappa$ B pathways play an important role in the synthesis of inflammatory cytokines and chemokines. Therefore, we performed experiments to evaluate the modulatory activity of DMC on the signaling pathways leading to NF- $\mathrm{BB}$ activation in TNF- $\alpha$-stimulated HaCaT cells. DMC significantly inhibited p65 phosphorylation in TNF- $\alpha$-stimulated HaCaT cells, indicating the modulation of the signaling cascades leading to NF- $\kappa$ B activation (Figure 6). In conclusion, the findings of the present study demonstrate for the first time that DMC inhibits the TNF- $\alpha$-treated expression of IL-6, IL-8, and CCL2/MCP-1 in HaCaT keratinocytes, and indicate that the inhibitory effect of DMC on the expression of these cytokines and chemokines is likely to be associated with the suppression of MAPKs (JNK and ERK) and NF-KB transcription factors. Our study suggests that DMC can be used as an alternative anti-inflammatory therapy for inflammatory skin diseases like psoriasis. Further studies on DMC therapy using in vivo models would be helpful in assessing the potential therapeutic effects on inflammatory skin.

Author Contributions: N.L. performed the experiments; Y.C.C., C.I.K., and S.-M.P. contributed reagents/materials/ analysis tools; C.-G.H. designed the experiments and wrote the paper.

Acknowledgments: This Study was supported by LINC $^{+}$Development Project of Jeju National University (2018) through the National Research Foundation of Korea funded by the Ministry of Education

Conflicts of Interest: The authors declare no conflict of interest.

\section{References}

1. Garcia, M.; Morello, E.; Garnier, J.; Barrault, C.; Garnier, M.; Burucoa, C.; Lecron, J.; Si-Tahar, M.; Bernard, F.X.; Bodet, C. Pseudomonas aeruginosa flagellum is critical for invasion, cutaneous persistence and induction of inflammatory response of skin epidermis. Virulence 2018, 9, 1163-1175. [CrossRef] [PubMed]

2. Wang, K.; Jiang, H.; Li, W.; Qiang, M.; Dong, T.; Li, H. Role of Vitamin C in Skin Diseases. Front. Physiol. 2018, 9, 819. [CrossRef] [PubMed]

3. Yang, J.H.; Yoo, J.M.; Cho, W.K.; Ma, J.Y. Anti-inflammatory effects of Sanguisorbae Radix water extract on the suppression of mast cell degranulation and STAT-1/Jak-2 activation in BMMCs and HaCaT keratinocytes. BMC Complement. Altern. Med. 2016, 16, 347. [CrossRef] [PubMed]

4. Yang, J.H.; Yoo, J.M.; Lee, E.; Lee, B.; Cho, W.K.; Park, K.I.; Yeul, M.J. Anti-inflammatory effects of PerillaeHerbaethanolic extract against TNF- $\alpha / \mathrm{IFN}-\gamma$-stimulated human keratinocyte HaCaT cells. J. Ethnopharmacol. 2018, 211, 217-223. [CrossRef] [PubMed]

5. Kong, L.; Liu, J.; Wang, J.; Luo, Q.; Zhang, H.; Liu, B.; Xu, F.; Pang, Q.; Liu, Y.; Dong, J. Icariin inhibits TNF- $\alpha /$ IFN- $\gamma$ induced inflammatory response via inhibition of the substance P and p38-MAPK signaling pathway in human keratinocytes. Int. Immunopharmacol. 2015, 29, 401-407. [CrossRef] [PubMed] 
6. Yang, J.H.; Hwang, Y.H.; Gu, M.J.; Cho, W.K.; Ma, J.Y. Ethanol extracts of Sanguisorba officinalis L. suppress TNF- $\alpha /$ IFN- $\gamma$-induced pro-inflammatory chemokine production in HaCaT cells. Phytomedicine 2015, 22, 1262-1268. [CrossRef] [PubMed]

7. Zhang, J.; Yang, X.; Wang, H.; Zhao, B.; Wu, X.; Su, L.; Xie, S.; Wang, Y.; Li, J.; Liu, J.; et al. PKCᄃ as a promising therapeutic target for $\mathrm{TNF} \alpha$-induced inflammatory disorders in chronic cutaneous wounds. Int. J. Mol. Med. 2017, 40, 1335-1346. [CrossRef]

8. Cho, J.W.; Lee, K.S.; Kim, C.W. Curcumin attenuates the expression of IL-1beta, IL-6, and TNF-alpha as well as cyclin E in TNF-alpha-treated HaCaT cells; NF-kappaB and MAPKs as potential upstream targets. Int. J. Mol. Med. 2007, 19, 469-474.

9. Choi, H.J.; Lee, J.H.; Jung, Y.S. (+)-Nootkatone inhibits tumor necrosis factor $\alpha /$ interferon $\gamma$-induced production of chemokines in HaCaT cells. BiochemBiophys. Res. Commun. 2014, 447, 278-284. [CrossRef]

10. Jung, T.D.; Choi, S.I.; Choi, S.H.; Cho, B.Y.; Sim, W.S.; Han-Xionggao; Lee, S.J.; Park, S.J.; Kim, D.B.; Kim, Y.C.; et al. Changes in the Anti-Allergic Activities of Sesame by Bioconversion. Nutrients 2018, 10, 210. [CrossRef]

11. Jeong, S.J.; Lim, H.S.; Seo, C.S.; Kim, J.H.; Jin, S.E.; Yoo, S.R.; Shin, H.K. Traditional herbal formula Jakyakgamcho-tang (Paeonia lactiflora and Glycyrrhiza uralensis) impairs inflammatory chemokine production by inhibiting activation of STAT1 and NF-kB in HaCaT cells. Phytomedicine 2015, 22, 326-332. [CrossRef] [PubMed]

12. Huang, W.C.; Dai, Y.W.; Peng, H.L.; Kang, C.W.; Kuo, C.Y.; Liou, C.J. Phloretin ameliorates chemokines and ICAM-1 expression via blocking of the NF- $\mathrm{kB}$ pathway in the TNF- $\alpha$-treatedHaCaT human keratinocytes. Int. Immunopharmacol. 2015, 27, 32-37. [CrossRef] [PubMed]

13. Tan, H.Y.; Zhang, A.L.; Chen, D.; Xue, C.C.; Lenon, G.B. Chinese herbal medicine for atopic dermatitis: A systematic review. J. Am. Acad. Dermatol. 2013, 69, 295-304. [CrossRef] [PubMed]

14. Kudo, K.; Hasegawa, S.; Suzuki, Y.; Hirano, R.; Wakiguchi, W.; Kittaka, S. 1 $\alpha$, 25-Dihydroxyvitamin D(3) inhibits vascular cellular adhesion molecule- 1 expressionand interleukin-8 production in human coronary arterial endothelial cells. J. Steroid Biochem. Mol. Biol. 2012, 132, 290-294. [CrossRef] [PubMed]

15. Schooling, C.M.; Au Yeung, S.L.; Freeman, G.; Cowling, B.J. The effect of statins on testosterone in men and women, a systematic review and meta-analysis of randomized controlled trials. BMC Med. 2013, 11, 1714-7015. [CrossRef]

16. Wu, C.; Feng, D.; Ma, H.; Xie, H.; Wang, H.; Wang, J. Effect of Pinusmassoniana bark extract on IFN-gamma-induced ICAM-1 expression in HaCaT human keratinocytes. J. Ethnopharmacol. 2009, 122, 48-53. [CrossRef]

17. Lee, J.H.; Jeon, Y.D.; Lee, Y.M.; Kim, D.K. The suppressive effect of puerarin on atopic dermatitis-like skin lesions through regulation of inflammatory mediatorsin vitro and in vivo. Biochem. Biophys. Res. Commun. 2018, 498, 707-714. [CrossRef]

18. Choi, J.K.; Jang, Y.H.; Lee, S.; Lee, S.R.; Choi, Y.A.; Jin, M.; Choi, J.H.; Park, J.H.; Park, P.H.; Choi, H.; et al. Chrysin attenuates atopic dermatitis by suppressing inflammation of keratinocytes. Food Chem. Toxicol. 2017, 110, 142-150. [CrossRef]

19. Li, Z.; Hu, J.; Sun, M.; Song, X.; Li, G.; Liu, Y.; Li, G.; Ji, H.; Liu, G.; Chen, N. In vitro and in vivo anti-inflammatory effects of IMMLG5521, a coumarin derivative. Int. Immunopharmacol. 2013, 17, 400-403. [CrossRef]

20. Pérez Gutiérrez, R.M.; Vargas Solis, R.; Garcia Baez, E.; Gallardo Navarro, Y. Hypoglycemic activity of constituents from Astianthusviminalis in normal and streptozotocin-induced diabetic mice. J. Nat. Med. 2009, 63, 393-401. [CrossRef]

21. Sood, S.; Muthuraman, A.; Gill, N.S.; Bali, M.; Sharma, P.D. Role of 7,8-dimethoxycoumarin in anti-secretary and anti-inflammatory action on pyloric ligation-induced gastritis in rats. J. Asian Nat. Prod. Res. 2010, 12, 593-599. [CrossRef] [PubMed]

22. Muthuraman, A.; Sood, S.; Ramesh, M.; Puri, K.D.; Peters, A.; Chauhan, A.; Arora, P.K.; Rana, A. Therapeutic potential of 7,8-dimethoxycoumarin on cisplatin- and ischemia/reperfusion injury-induced acute renal failure in rats. Naunyn-Schmiedeberg's Arch. Pharmacol. 2012, 385, 739-748. [CrossRef] [PubMed]

23. Misra, L.N.; Wouatsa, N.A.; Kumar, S.; Kumar, R.V.; Tchoumbougnang, F. Antibacterial, cytotoxic activities and chemical composition of fruits of two Cameroonian Zanthoxylum species. J. Ethnopharmacol. 2013, 148, 74-80. [CrossRef] [PubMed] 
24. Huang, E.; Xu, M.; Yang, J.; Xi, H.; Xu, D. Chemical studies on the constituents of Daphne koreane Nakai. ZhongguoZhong Yao ZaZhi 1990, 15, 609-610. [CrossRef]

25. Sung, Y.Y.; Kim, Y.S.; Kim, H.K. Illiciumverum extract inhibits TNF- $\alpha$ - and IFN- $\gamma$-induced expression of chemokines and cytokines in human keratinocytes. J. Ethnopharmacol. 2012, 144, 182-189. [CrossRef] [PubMed]

26. Seo, S.H.; Jeong, G.S. Fisetin inhibits TNF- $\alpha$-treated inflammatory action and hydrogen peroxide-induced oxidative damage in human keratinocyte HaCaT cells through PI3K/AKT/Nrf-2-mediated heme oxygenase-1 expression. Int. Immunopharmacol. 2015, 29, 246-253. [CrossRef] [PubMed]

27. Li, D.; Wu, L. Coumarins from the roots of Angelica dahurica cause anti-allergic inflammation. Exp. Ther. Med. 2017, 14, 874-880. [CrossRef] [PubMed]

28. Pereira, T.M.; Franco, D.P.; Vitorio, F.; Kummerle, A.E. Coumarin Compounds in Medicinal Chemistry: Some Important Examples from the Last Years. Curr. Top. Med. Chem. 2018, 18, 124-148. [CrossRef] [PubMed]

29. Stefanachi, A.; Leonetti, F.; Pisani, L.; Catto, M.; Carotti, A. Coumarin: A Natural, Privileged and Versatile Scaffold for Bioactive Compounds. Molecules 2018, 23, 250. [CrossRef]

30. Fiorito, S.; Epifano, F.; Preziuso, F.; Cacciatore, I.; di Stefano, A.; Taddeo, V.A.; de Medina, P.; Genovese, S. Natural oxyprenylatedcoumarins are modulators of melanogenesis. Eur. J. Med. Chem. 2018, 152, 274-282. [CrossRef]

31. Yang, J.Y.; Koo, J.H.; Song, Y.G.; Kwon, K.B.; Lee, J.H.; Sohn, H.S.; Park, B.H.; Jhee, E.C.; Park, J.W. Stimulation of melanogenesis by scoparone in B16 melanoma cells. Acta Pharmacol. Sin. 2006, 27, 1467-1473. [CrossRef] [PubMed]

32. Li, J.; Li, X.; Li, Z.; Zhang, L.; Liu, Y.; Ding, H.; Yin, S. Isofraxidin, a coumarin component improves high-fat diet induced hepatic lipid homeostasis disorder and macrophage inflammation in mice. Food Funct. 2017, 8, 2886-2896. [CrossRef] [PubMed]

33. Shen, L.; Zhou, T.; Wang, J.; Sang, X.; Lan, L.; Luo, L.; Yin, Z. Daphnetin reduces endotoxin lethality in mice and decreases LPS-induced inflammation in Raw264.7 cells via suppressing JAK/STATs activation and ROS production. Inflamm. Res. 2017, 66, 579-589. [CrossRef] [PubMed]

34. Kim, H.J.; Jang, S.I.; Kim, Y.J.; Chung, H.T.; Yun, Y.G.; Kang, T.H.; Jeong, O.S.; Kim, Y.C. Scopoletin suppresses pro-inflammatory cytokines and PGE2 from LPS-stimulated cell line, RAW 264.7 cells. Fitoterapia 2004, 75, 261-266. [CrossRef] [PubMed]

35. Liao, W.; Liu, Z.; Zhang, T.; Sun, S.; Ye, J.; Li, Z.; Mao, L.; Ren, J. Enhancement of Anti-Inflammatory Properties of Nobiletin in Macrophages by a Nano-Emulsion Preparation. J. Agric. Food Chem. 2018, 66, 91-98. [CrossRef] [PubMed]

36. Chung, Y.C.; Kim, S.; Kim, J.H.; Lee, G.S.; Lee, J.N.; Lee, N.H.; Hyun, C.G. Pratol, an O-Methylated Flavone, Induces Melanogenesis in B16F10 Melanoma Cells via p-p38 and p-JNK Upregulation. Molecules 2017, 22, 1704. [CrossRef] [PubMed]

37. Yoon, H.S.; Ko, H.C.; Kim, S.S.; Park, K.J.; An, H.J.; Choi, Y.H.; Kim, S.J.; Lee, N.H.; Hyun, C.G. Tangeretin triggers melanogenesis through the activation of melanogenic signaling proteins and sustained extracellular signal- regulated kinase in B16/F10 murine melanoma cells. Nat. Prod. Commun. 2015, 10, 389-392. [CrossRef] [PubMed]

38. Kang, N.J.; Koo, D.H.; Kang, G.J.; Han, S.C.; Lee, B.W.; Koh, Y.S.; Hyun, J.W.; Lee, N.H.; Ko, M.H.; Kang, H.K.; et al. Dieckol, a Component of Ecklonia cava, Suppresses the Production of MDC/CCL22 via Down-Regulating STAT1 Pathway in Interferon- $\gamma$ Stimulated HaCaT Human Keratinocytes. Biomol. Ther. 2015, 23, 238-244. [CrossRef]

(C) 2019 by the authors. Licensee MDPI, Basel, Switzerland. This article is an open access article distributed under the terms and conditions of the Creative Commons Attribution (CC BY) license (http://creativecommons.org/licenses/by/4.0/). 